\title{
"Her lost girl": Shirley Jackson and Kenneth Burke in the Bennington Triangle
}

\section{Henry King}

Independent scholar

\begin{abstract}
From 1945 to 1950, a number of unexplained disappearances occurred in the vicinity of Bennington, Vermont. During the same period, the author Shirley Jackson moved to North Bennington, while her friend Kenneth Burke (a colleague of her husband at Bennington College) published two pivotal works of theory, A Grammar of Motives (1945) and A Rhetoric of Motives (1950). Although the disappearances have previously been noted as a context of Jackson's fiction, especially the short story "The Missing Girl", this article applies a Burkeian lens to analyse how Jackson used the disappearances to explore the effects of what Burke calls "the hierarchal psychosis" on young women and rural New England society.
\end{abstract}

Keywords: Shirley Jackson; Kenneth Burke; short fiction; rhetoric; scapegoating

Shirley Jackson spent almost her whole writing career, from her first succès de scandale with "The Lottery" in 1947 to We Have Always Lived in the Castle in 1962, living in the small rural town of North Bennington, Vermont. Born in San Francisco in 1916, her family moved to Rochester, NY when she was in high school; while studying journalism at Syracuse University and editing the campus magazine, she met her future husband, Stanley Edgar Hyman. Jackson and Hyman moved to Vermont with their young family in 1945, when Hyman took a teaching position at Bennington College, then a women's liberal arts institute with an experimental ethos. Although Hyman would first teach there for just one year before returning to the faculty permanently in 1953, the family remained in North Benning- 
ton (apart from a spell in Connecticut through 1949-51) until Jackson's early death in 1965, at the age of forty-eight.

Hyman's appointment at Bennington had been influenced by a friend already on the faculty: Kenneth Burke (Franklin 189). Burke, born in Pittsburgh in 1897, dropped out of Columbia University to write fiction and poetry, but then began on critical works that expanded beyond literature into philosophy and social criticism; this growing oeuvre made up for his lack of a degree when he joined Bennington in 1942. The year Jackson and Hyman arrived, Burke published the pivotal book of his career, A Grammar of Motives, intended to be the first in a series known as the 'Motivorum'; the second, A Rhetoric of Motives, followed in 1950. Thus, despite absences to write and teach elsewhere, Burke's most fertile period coincided with those early "Bennington days when Stanley Hyman and Shirley Jackson were being very lively there," as he would later recall ("Ralph Ellison's Trueblooded Bildungsroman" 104). The intellectual as well as social intimacy between Jackson and Burke (and his wife Libby, who became a close friend) is attested by the fact that one of the few references to contemporary literature in his Rhetoric is to Jackson's debut novel, The Road Through the Wall, published in 1948; that this occurs within a discussion of Kafka's The Castle suggests his high regard for her fiction (242).

Though heady times for the Bennington literati, the period was marked by a number of disturbing events. Between 1945 and 1950, at least five people disappeared in the vicinity of Bennington; the true number is hard to fix, as different sources offer different counts, but five are sure. ${ }^{1}$ The first, an elderly but experienced woodsman named Middie Rivers, vanished without a trace on November 12, 1945 while guiding a group of hunters. The second struck closer to home: Paula Jean Welden was a Bennington sophomore when she went for a hike on December 1, 1946, and was never seen again. On December 1, 1949, the third anniversary of Welden's last sighting, James Tedford was returning from St Albans to Bennington by bus; he never arrived, with no one able to say that he had ever alighted. The next two disappearances both occurred in October 1950: eight-year-old Paul Jephson vanished from the municipal dump, where his mother worked, on the $12^{\text {th }}$; Frieda Langer, an active woman of fifty-three who knew the area well, vanished in the woods on the $28^{\text {th }}$. Langer's was the only body ever found, yet this raised more questions than it answered: her remains were

1 Bernice M. Murphy says seven people disappeared (125), while Joseph Citro suggests that "perhaps ten in all" went missing (Passing Strange 88), yet focuses on these five. 
discovered the following spring in open ground that had been exhaustively searched in the autumn.

These events led Joseph A. Citro to coin the phrase "the Bennington Triangle" (87), playing on the supposed disappearances of ships and planes in the Bermuda Triangle. Citro, a science fiction author and anthologist of New England myth and folklore, indulges in speculation about paranormal explanations, including alien abductions and a Bigfoot-like "Bennington Monster" (92), as well as the possibility of a serial killer roaming the area. Perhaps from simple ignorance, he does not mention the coincidence that Bennington was then home to one of the great horror writers of the twentieth century.

Jackson scholars, however, have noted the disappearances as a context for her fiction. Bernice M. Murphy notes that the short story "The Missing Girl" "may have been suggested by" the Welden disappearance (109), and that both it and "Louisa Please Come Home" "seem to be obvious fictionalizations of the case" (125, note 1). Murphy also compares Welden vanishing in the Vermont woods to the conclusion of Jackson's second novel, Hangsaman, in which the protagonist, Natalie Waite, "emerges from the woods" as "one of the lucky ones" (109). Jackson's first biographer, Judy Oppenheimer, agrees that "it seems likely" Welden's disappearance "had a strong effect on her" (145) and on the composition of Hangsaman. The disappearance forms a subplot in the fictionalized biopic Shirley (2020), directed by Josephine Decker and adapted from the novel by Susan Scarf Merrell (herself a graduate of Bennington's MFA program), in which Jackson (played by Elizabeth Moss) is portrayed as investigating the case and basing Hangsaman on it. (Welden's disappearance also influenced the plot and setting of Donna Tartt's debut novel The Secret History, begun when she too was at Bennington in the mid-1980s). In the most recent biography, Ruth Franklin affirms that "The Missing Girl" is "explicitly based on Welden's disappearance," evidenced by the fact that Jackson kept a file of newspaper clippings related to the search, and took the title from one these (254). Contrary to those critics who claim Hangsaman is likewise modelled on the Welden case, though, Franklin asserts that "there is no evidence for this" (542).

Curiously, Jackson herself denied basing a story on the case. In a 1960 letter to her friend Jeanne Beatty, Jackson writes that she came across Welden again "in a cheap collection of sensational articles on missing persons" (The Letters of Shirley Jackson 484). Describing the events as forming "such a lovely story," Jackson claims that she "always wanted to write it, but can't, 
of course" (484); were she to do so, she says, she would change the setting from Bennington, and avoid writing about the local police and FBI's lackadaisical investigations. She also discusses "our other classic case, which is the story of middie rivers" ( $s i c ; 485)$, but none of the others. Although this seems to undermine the connection between Welden and "The Missing Girl", Jackson's account in the letter is not wholly accurate: she says Welden disappeared "about ten years ago," i.e. circa 1950 (only four years out), but that Rivers vanished "seven years ago" (485), when in fact he disappeared the year before Welden. This may be a sign that her memory is unreliable (unsurprisingly, given her poor mental and physical health in the last years of her life), which may extend to her own creative process. As I shall argue, the text contains evidence to suggest that Paula Welden was, as the critics generally agree, the model for "The Missing Girl".

Placing the story in the context of Paula Welden's disappearance usually exhausts the critics' attention to it, when they discuss it at all; Darryl Hattenhauer, for example, makes no mention of it in Shirley Jackson's American Gothic (2003); nor does Oppenheimer. Others such as Joan Wylie Hall and Angela Hague have discussed it from a feminist perspective without referring to Welden's disappearance, characterising it instead as one of Jackson's stories about the "[i]nvisibility, powerlessness, and lack of identity" (Hague 81) that afflict young women in patriarchal post-war America. Critics have seemingly either found the connection to Welden's disappearance to be the story's only notable feature, or irrelevant to it its interpretation. What both tendencies lack is a way of thinking about how Jackson uses the disappearance to explore her recurrent themes - invisibility, powerlessness, and lack of identity included.

However, if we add to the context of the Bennington disappearances a second circumstance - Kenneth Burke's writing A Rhetoric of Motives - we find a theoretical apparatus that does justice to the detail and structure of "The Missing Girl". We cannot be certain that Jackson had advance notice of the ideas Burke was developing, although it is quite possible that she did, either directly - Hyman once said Burke possessed "the finest brain and the loosest tongue" (Franklin 115) - or via her husband. What we do know is that Burke, by helping Hyman into a job, inadvertently positioned Jackson to write "The Missing Girl". The next step, then, must be a synopsis of Burke's Rhetoric. 


\section{A Rhetoric of Motives}

Burke's ambition in his 'motivorum' was to create a modern equivalent of Aristotle's comprehensive system of logic, ethics, rhetoric, and poetics. The first volume, A Grammar of Motives, lays the logical foundations, covering the "resources of definition and placement common to all thought" (Rhetoric 21). The Rhetoric develops this by dealing with "the possibilities of classification in its partisan aspects; it considers the ways in which individuals are at odds with one another, or become identified with groups more or less at odds" (22). That this work was begun at the end of the Second World War and the start of the Cold War suggests the urgency of Burke's purpose.

The emphasis on classification underpins Burke's attempt to move beyond the Aristotelian definition of rhetoric as persuasion, instead conceptualising it in terms of identity and difference. As Burke argues, "difference is not felt merely as between this entity and that entity. Rather, it is felt ... as between this kind of entity and that kind of entity" (176-177) For Burke, this arises from human nature as "a symbol-using animal" (282): the nature of language is to divide the world, not into an infinite series of unique phenomena, but into categories, classes, kinds, which can themselves be grouped in classes of increasing generality. These operations - dividing by specific differences; unifying by general similarities - are the primary resources of dialectic, discussed in A Grammar of Motives. As a result, "communication between entities becomes communication between different classes of entities" (177).

Perhaps surprisingly given the Cold War context, Burke models his analysis not on bellicose but amatory relations, claiming that "persuasive communication between kinds (that is, persuasion by identification) is the abstract paradigm of courtship. Such appeal, or address, would be the technical equivalent of love" (177). This does not mean that rhetoric is always conducted in a loving spirit, but that all rhetoric is courtship in presupposing difference between the parties involved, which the addresser aims to bridge by identifying the addressee's interests with their own.

One advantage of courtship as a governing metaphor is that is has both private and public dimensions. As Burke points out, "differences between the sexes has its analogue in the difference between social classes" (177). ${ }^{2}$

2 Burke's assumption here is clearly heteronormative, but the vectors of difference are so many that homosexual relations are marked by other forms mystery - including the difference between the 'classes' of wooer and wooed. 
The courtier pays homage to the sovereign, the lover courts the beloved, and both relationships can be seen in terms of the other: the beloved is placed in a position of princely superiority, and relations between courtier and prince take on an erotic aspect. Thus, Burke reads texts from Shakespeare's "Venus and Adonis" to Kafka's The Castle as examples of how power relations are figured in sexual terms, and vice versa. These examples also demonstrate that courtship implies hierarchy. As he puts it in the contemporaneous essay "On Human Behavior Considered 'Dramatistically", 3 once classes have been established "there must be some 'order' among these classes", which "involves a distribution of authority. And such mutuality of rule and service, with its uncertain dividing-line between loyalty and servitude, takes roughly a pyramidal or hierarchal form" (276).

Although Burke argues that "classification in this linguistic, or formal sense is all-inclusive, 'prior' to classification in the exclusively social sense" (Rhetoric 282), this should not be taken to mean that he sees social class as a purely symbolic phenomenon: that would overstress humankind's specific nature as a symbol-using animal over its generic nature as symbolusing animal. Rather, social class results from the symbolic transformation of biological necessity. Burke argues that "the roots of ownership ... reside in the individual centrality of the nervous system," as when "[w]hat the body eats and drinks becomes its own special private property" (130). But humans are not simply individuals; they are social beings whose sociality is mediated through language. Thus the "underlying biological incentive towards private property" is complicated by "the fact that the high development of production and language owes so much to its public or communal nature" (130). "And once a high development of public property has accumulated," he continues, private property becomes "rather a function of that accumulation than an expression of the original biologic goading" (130). Social class, Burke therefore argues, has material causes and forms of expression, but the "invidious' aspects of class arise not from the nature of man as a 'class animal,' but as a 'classifying animal'" (283).

But perhaps Burke's most intriguing point is that rhetorical courtship involves mystery. Mystery "arises at that point where different kinds of beings are in communication. In mystery there must be strangeness; but the

3 The essay is "a somewhat reworked version of a paper that was originally presented in a symposium on 'Organizational Behavior,' held at Princeton University in 1951” (fn. 274), where he completed revisions to A Rhetoric of Motives. 
estranged must be thought of as in some way capable of communion" (115; emphasis in original). A person of one kind never quite knows what someone of another has in mind; they are always somewhat mysterious to each other, so their mutual understanding and cooperation must be coordinated rhetorically. Hence, a hierarchic form of mystery results from "any pronounced social distinctions, as between nobility and commoners, courtiers and king, leader and people, rich and poor, judge and prisoner at the bar, 'superior race' and underprivileged 'races' or minorities" (115; emphasis in original). In literature, for example, "the story of relations between the petty clerk and the office manager, however realistically told, draws upon the wells of mystery for its appeal, since the social distinction between clerk and manager makes them subtly mysterious to each other" (115). In light of this, Burke reviews previous analyses of mystery in class relationships, whether seen negatively, as by Marx, positively, as by Thomas Carlyle in Sartor Resartus, or ironically, as in William Empson's Some Versions of Pastoral. Burke's aim is not to prove Marx or anyone else right or wrong, but demonstrate what each contributes to our understanding of the rhetoric of social relations.

The mystery foundational to rhetorical courtship can be seen in "the respect, reverence, embarrassment, and ironies that go with intercourse between classes" (177). If respect and reverence are rhetorical forms of social cohesion, and embarrassment and irony are symptoms of social breakdown, then the latter predominate, because "in any social inequality there is awkwardness" (126). In "On Human Behavior" this is put even more starkly: "As Mystery is the obverse expression of the disrelationship among classes, so the reverse expression is Guilt", while embarrassment is "an attitude midway between" (278). The results of these affects are not always courteous, as Burke, a fellow-traveller of American socialism, knew. Indeed, "the relations between the classes are like the ways of courtship, rape, seduction, jilting, prostitution, promiscuity, with variants of sadistic torture or masochistic invitation to mistreatment" (Rhetoric 115).

If mystery and guilt are fundamental rhetorical motives, then the paradigmatic form of this, Burke argues, is the relationship between human beings and God, according to which "the divisive condition in which all men share is called "Original Sin"" (Rhetoric 148). This names "categorical Guilt, one's 'guilt' not as the result of any personal transgression, but by reason of a tribal or dynastic inheritance" ("On Human Behaviour" 278) - guilt deriving from one's inevitable membership of a class. The religious 
paradigm also suggests a way to atone for this guilt: through sacrifice. This is the pattern Burke sees "behind the doctrinal placement of the Crucifixion, and the pattern of Greek tragedy (nor should we forget the other great line from which the doctrines of our culture are derived, in this instance the lore of Azazel)" ("On Human Behavior" 285) - that is, the rites for selecting a scapegoat codified in Leviticus 16 . Such victimage produces catharsis, ritual cleansing. The sacrificial offering in these traditions - Christ, Oedipus, the scapegoat - is made "ritually perfect" ("On Human Behavior" 284), whether through priestly or dramatic preparation, or post hoc through theology, and thus corresponds to the absolute, categorical nature of the guilt to be absolved.

But not all guilts are so absolute, and "insofar as the 'guilt' were but 'fragmentary,' a victim correspondingly 'fragmentary' would be adequate for the redeeming of such a debt" ("On Human Behavior" 284). Burke saw fragments of catharsis scattered throughout American culture: one in "the corpse of a murder mystery, another in the butchery of a prize-fight, another in a hard-fought game, another in the momentary flare-up of a political campaign, another in a practical joke played on a rival at the office, another in weeding the garden or ferociously rubbing out a cigarette butt, etc." ("On Human Behavior" 287). The drawback of such " "fragmentary' scapegoats", however, is that they can be "fantastically and morbidly irrelevant" to the real causes of social ills, as with Nazi antisemitism ("On Human Behavior" 284). Similarly, at the beginning of the Cold War, Burke again found nations, "in their quarrels over property, preparing themselves for the slaughter" (Rhetoric 264).

Thus, the ultimate outcome of human nature as a symbol-using animal is that hierarchical societies become saturated with mystery, guilt, and the need for ritual victims for cathartic expiation - a package Burke sums up under the name of the "hierarchal psychosis" ("On Human Behavior" 293). In these circumstances, the Burkeian critic's role is "to attempt analyzing the tricky ways of thought that now work to complete the devotion of killing" (Rhetoric 264).

\section{"The Missing Girl"}

Such was the theory Burke was formulating when Paula Welden disappeared from Bennington and Shirley Jackson wrote "The Missing Girl". Reduced to a pair of heuristic directives for reading the story, the first would be to "interpret any variants, however twisted or attenuated, of embarrassment in 
social intercourse as sign of a corresponding mystery in communication" (Rhetoric 208). The second would be that, where a narrative involves victimage (whether in the form of death, or attenuated as humiliation), look for sacrificial cleansing and atonement. We will follow these directives in turn.

The story begins with the protagonist in her room at the Phillips Educational Camp for Girls Twelve to Sixteen, humming absentmindedly, to the irritation of her studious room-mate Betsy. Eventually the girl announces that she is "going out" because she has "something to do" (339). By the following evening, Betsy has not seen her again, and the next day she begins to worry. When she thinks of alerting the head of the camp, though, she fears embarrassment, ventriloquising others' reactions should she raise a false alarm: "Did you hear about Betsy? Went tearing off to old Auntie Jane to say her room-mate was missing, and here all the time the poor girl was..." (340). But when on the third day she asks someone if she should report the girl's absence, they tell her "it might mean trouble for you if she's really missing" (340). Betsy is thus trapped in a double bind, exposed to ridicule if nothing is wrong, and to blame if something is.

"Auntie Jane" is the Camp Mother, usually referred to as Old Jane. Her titles figure her hierarchic position in familial terms, as the head of a family over and against a subordinate class of children. She is described as "comfortable and tolerant and humorous," and "wise enough to give the strong impression of experience" (340) - that is, she employs what Burke calls "a rhetoric of charitable condescension" (Rhetoric 118) towards her subordinates, yet knows to maintain the "mystery of rule" (158). Thus, the first scene marked by hierarchic tensions occurs when Betsy finally tells Jane about the missing girl.

Their interview reveals more about the gradations of hierarchy within the camp. When asked to which age-group the missing girl belonged, Betsy replies "Woodsprite, I think," because "I'm a woodsprite, I mean, and they usually put woodsprites in with woodsprites and goblins in with goblins and senior huntsmen in with - " (341). Jackson reinforces the importance of these classes by repeating them in a later interview, when Old Jane asks Betsy how long she had roomed with the missing girl: "we both put in for rooms at the same time and so they put us together again. I mean, most of my friends are senior huntsmen and of course I can't room with them because they only put senior huntsmen with-" (343). This repetition suggests that a hierarchal psychosis is endemic to the camp, and important to the story's motivations. 
In the first interview, Betsy identifies the missing girl as Martha Alexander, from "New York ... I think" (340). When the girl's mother confirms by telephone that she has not come home, Old Jane brings in the local police, led by Chief Hook. In introducing this representative of the nearby town, Jackson emphasizes the disconnect between them: this is "the first time the chief of police ... had ever been required to visit a girls' camp; his daughters had not gone in much for that sort of thing, and Mrs Hook distrusted night air" (341). Chief Hook is to the town much as Old Jane is to the camp: although the dimwitted policeman is dependent on others' confidence, he "had been allowed to continue in office this long because his family was popular in town and the young men at the local bar liked him, and because his record for twenty years, of drunks locked up and petty thieves apprehended upon confession, had been immaculate" (341-342). But their similar status in adjacent realms creates awkwardness: Chief Hook is "visibly afraid his questions would sound foolish to Old Jane", and even "put[s] out his cigar in deference to the camp nurse" (342); he also shows "some embarrassment" (343) when he helps search the girls' room, no doubt caused in part by his status as a man in a feminine domain. Conversely, when Betsy is questioned again, Old Jane's tone is "faintly sardonic, as though in deference to Chief Hook she were forced to restrain the saltier half of her remark" (343).

Thus, in addition to the mysteries of hierarchy internal to the camp, Jackson structures the story around the external mystery of relations between camp and town. To put it dialectically, the camp, considered internally with its group nature taken for granted, is divided into ranked classes; but its unified aspect predominates when considered externally, in contrast with its division from the town. The townsfolk perceive the girls generically: a local housewife who saw someone on the road "figured she was one of those girls from the camp" because "she was wearing pants" (345), as if this could not have applied to a girl from town; a man who picked up a hitchhiker asserts, "I don't think she was a camp girl ... not the way she talked, she wasn't any girl from the Phillips Camp, not her" (345-346), as if all camp girls speak alike.

The next act of the story is a sequence of interviews with the camp's counselors, from which the only conclusion is that they know nothing about Martha Alexander, or indeed about any of their charges. Nor does the camp's bureaucracy help: "most of the counselors kept slipshod attendance records, and none of them could remember whether any such girl could 
have come on any given day" (344); similarly, "the picture on her camp application blank was so blurred that it resembled a hundred other girls in the camp" (345). As the librarian wistfully tells Chief Hook, "one girl is much like another, at this age. Their unformed minds, their unformed bodies, their little mistakes" render them interchangeable, and though the counselors, likewise, "were young once" (344), the veil of seniority (in both age and position) have rendered their subordinates mysterious. They are only perceived generically, as members of a class, not in their specificity as individuals. As "the muscular young woman who was known as Tarzan because she taught swimming" bluntly puts it, "did you ever look at fifty girls all in white bathing caps?" (344) Conversely, the adults are baffling to the girls: when asked the same questions for the umpteenth time, Betsy reaches "that point of stubbornness most thirteen-year-old girls have, when it seems that adult obscurity has passed beyond necessity" (342) - implying that there is always a degree of obscurity, mystery, to adult ways.

The first implication of the search, therefore, is that Martha Alexander did not just go missing: thanks to the mysteries of hierarchy separating young from old, "the class of students" from "the class of teachers" (Burke, Rhetoric 178), she had been missed the whole time she was at the Phillips Camp. These two senses of "miss' - "to discover or feel the absence of"; "to fail to comprehend, sense, or experience" ("miss", Merriam-Webster) - form the hinge of the story. (It is an apt coincidence that the title for a girl is Miss.) Burke points out that, besides social mystery, there are "the mysteries of dream, of creation, of death, of life's stages, ... of adventure and love," the point being not to reduce "mystery in general to the social mystery in particular", but that "social mystery gains in depth, persuasiveness, allusiveness and illusiveness precisely by reason of the fact that it becomes inextricably interwoven with mysteries of these other sorts, quite as these other mysteries must in part be perceived through the fog of the social mystery" ("On Human Behavior" 277). Jackson uses the narrative mystery of the girl's disappearance to expose the social mystery imposed on young women by institutions such as summer camps.

But where there is mystery, Burke reminds us, there is guilt; and where there is guilt, look for expiation through victimage. With this in mind, Martha Alexander may be seen not as a lost sheep but as a scapegoat: like the one chosen by lot in Leviticus, the "something" she has "got to do" is to make atonement by going out, alone, into the wilderness. Like Tessie Hutchinson in "The Lottery", Martha Alexander is sacrificed (not by a hu- 
man agent, so far as we know, but by the symbolic logic of the story) to restore the integrity of the group.

But this only accounts for the camp's internal divisions, not the external division between the camp and the town. Despite Chief Hook's awkwardness, the search initially leads to cooperation between these groups: "girls from the camp, led by the counselor in nature study and the senior huntsmen," comb the mountain with "the assistance of chosen boy and girl scouts from the town" (346); "the seventeen-year-old son of the owner of the local paper was given first chance at all new developments", and the camp takes up his suggestion "that a search be made over Bad Mountain by helicopter", although a complaint about the "tremendous expense" this incurs suggests another embarrassment between the middle-class camp and the newspaper magnate's son, who "subsequently informed his father that he preferred having a plane to inheriting the paper" (346).

If her body were found, the scapegirl might reconcile camp and town; but as the search drags on without result, mutual suspicion and hostility flare up. Here, Jackson's narration mimics the rustic idiom of the townspeople, who believe "it would be mighty easy for anyone to miss a body in them woods; go ten feet off the path and you're lost, and the mud that deep already", and ironically suggests the rhetorical strategy by which animosity assumes the guise of regret: "it was generally conceded in the town that the girl had been followed in the darkness by a counselor from the camp, preferably one of the quiet ones, until she was out of sight or sound of help" (347). This belief is motivated in part by the economic dimension of the hierarchal psychosis: for the locals, the rape of a subordinate by a camp leader would symbolize the theft underlying the unequal distribution of property in the social order, furnishing a kind of substitute proof of the fact that they, as the economically weaker group, are exploited by the visitors.

The outsiders' vituperation is even more extreme, denouncing the locals' "general vulgarity and insolence, and the generations of inbreeding that had led to idiocy in half the families and just plain filth in the rest" (347). Their conclusion that a townsperson must have "enticed the girl off into an assignation on the mountain, and there outraged and murdered her and buried her body" (347) is premised, at least in part, on the fear that this "courtship, rape," and "torture" (Burke, Rhetoric 115) symbolizes theft from the propertied by the relatively poor and socially subordinate. Whatever the awkward courtesies between Old Jane and Chief Hook, the neighboring com- 
munities have at this point reached "the stage of blunt antithesis" (Burke, Rhetoric 142).

These resentments are functions of the scapegoat mechanism. As Burke argues, by "splitting the hierarchic principle into factions," the scapegoat "becomes ritually gratifying; for each faction can then use the other as katharma, the unclean vessel" (Rhetoric 141) - that is, the townsfolk and the campers assign to one another not only the blame for the disappearance, but their own feelings of guilt. The locals, whose "grandfathers had known of people disposed of in just that way" (347), load their iniquities on the outsiders; the campers, whose failings have been exposed, execrate "a retarded village in an isolated corner of the world," claiming "you might go far before you met up with a lower and stupider group of clods" (347). Burke points out that this mechanism is "made all the more zealous by the secret awareness that, if not thus morally 'protected,' each faction might 'court' the other" (Rhetoric 141), as indeed the visitors did when they held "the Camp Talent Show early in the summer, to which the townspeople had been invited" (347). These anxieties mean that their concern for the girl shades into desire for her murder, as both sides imaginatively sacrifice her on the altar of social competition.

Finally, when the boy and girl scouts have quit and Chief Hook suggests that "we might as well give it up" (347), the search is turned on its head. The girl's uncle, who came to direct the hunt, reveals that Martha Alexander's mother is "pretty sure ... that she decided against Phillips Educational Camp for Girls" (348), and indeed has only three daughters, named Helen, Jane, and Mabel. Old Jane confirms that although "a girl named Martha Alexander applied for admission to the Phillips Educational Camp for Girls Twelve to Sixteen, her application was put into the file marked "possibly undesirable' and there is no record of her ever having come to the camp" (349). The girl was missed, both before and after her disappearance, more comprehensively than they had realized.

Yet Jackson delivers a final twist. "A body that might have been Martha Alexander's was found, of course, something over a year later, ... stuffed away among some thorn bushes, which none of the searchers had cared to tackle"; however, the corpse's looks and clothing are unrecognizable to Betsy, "a senior huntsman the past summer but rooming alone" (349). She and Old Jane, who attends the funeral "as befitted the head of the camp", stand "alone in the cemetery beside the grave" (349), unaccompanied by any of the townspeople: if any of them had missed a friend or relative of their own, 
they have not come forward to claim her. The story ends with the Camp Mother enacting a gesture of grief for a girl who has, in death, become identified with the one who disappeared: "Although she did not cry over her lost girl, Old Jane touched her eyes occasionally with a plain white handkerchief, since she had come up from New York particularly for the services" (349). If the Camp Mother can mourn for a stranger, perhaps a local, then the story concludes with a sliver of reconciliation between the groups. Yet the punctiliousness of the final clause withholds such cathartic purgation.

\section{Missing Shirley Jackson}

A focus on the formal structures of hierarchical mystery and scapegoating may seem to sideline the ways in which "The Missing Girl" reflects the Bennington disappearances. These include Chief Hook's reference to having "[1]ost a hunter last fall" (345), which may allude to Middie Rivers' disappearance while guiding four hunters in November the year before Paula Welden vanished - an inference supported by the fictional toponym "Muddy River" (347), a pun on the vanished hunter's name. And in a turn of events Jackson might have scripted, Welden's father “claimed that a clairvoyant from Pownal insinuated a man's involvement in Paula's disappearance" (Robinson), forming the basis for the camp nurse's declaration that "she had for a long time been renowned as a minor necromancer and seer, and would gladly volunteer her services in any possible psychic way" (347). Jackson was herself to prove clairvoyant in one respect: much like the discovery of a different body at the story's conclusion, "13 years later, an unidentified skeleton was found in Adams. Investigators excitedly awaited the results of an analysis on the bones, only to find that they were too old to have possibly been Paula's" (Robinson). However, the absence of textual allusions to the later disappearances, and the fact that from 1949 through 1951, when the last three disappearances occurred, Jackson and her family were living in Westport, Connecticut (Franklin 270) -coincidentally, just ten miles from Paula Welden's hometown of Stamford - suggest that the story was written before those subsequent events compounded the sense of mystery around Bennington. Given the way Jackson pokes fun at the nurse's paranormal pretensions and avoids the wilder explanations later mooted by Joseph Citro, it is ironic that the story was first published in the December 1957 issue of The Magazine of Fantasy \& Science Fiction, which had that year featured fiction by masters of supernatural horror such as Richard Matheson and H.P. Lovecraft. 
But referring the details of the story back to the events of December 1946 can connect its representation of the hierarchic psychosis to Jackson's other fiction, and to her experience of New England. Insofar as the Phillips Educational Camp substitutes for Bennington College, the story is another working-through of the tension between the local population and "the sometimes-resented academic community that had sprung up around the recently built college" (Murphy 106) with which Jackson and her family were identified. It clearly fits the Jacksonian subgenre of stories portraying "the relationship between newcomers and locals in small, insular, and often deeply prejudiced New England communities" (Murphy 110). But whereas, in most of these, "insecure city folk" are "humbled" (Murphy 110) by their encounters with their ruthless rural neighbors, "The Missing Girl" has a more complex dynamic, with initial estrangement replaced first by cooperation, then competition, followed by ambiguous reconciliation. In part, this may simply be a result of how early in their residence the story was written, before "relations between her and the townspeople of Bennington deteriorated over the years" (Murphy 124).

Although critics are divided over whether Paula Welden's disappearance was a model for Hangsaman, the novel resembles the short story in that both explore the hierarchic tensions within educational institutions for girls. Natalie Waite's college is more directly based on Bennington, but there is an analogous hierarchy between her status as "frosh" (Hangsaman 56) - i.e. new - and the missing girl's as a woodsprite, apparently a junior age-group. But while the courtship between orders in the Phillips camp is chaste compared with that in the novel between English professor Arthur Langdon and his students Vicki and Anne, the locals' conviction that the missing girl was raped and murdered by a counselor may symbolize the logical conclusion of the belief, widespread in North Bennington, that sexual relations between students and faculty were the norm on campus - logical conclusions being fictionally represented, as Burke notes, by "a narrative figure whose acts led to some fitting form of death" (Rhetoric 14; emphasis in original). (Indeed, courtship between Bennington faculty and students was rampant, as Franklin shows (196).) In Hangsaman, one victim of the college's hierarchal psychosis is Elizabeth, formerly Langdon's student and now his humiliated, alcoholic wife - clearly representing some of Jackson's feelings about her status as a "faculty wife" (Jackson, Raising Demons 147). In this role, Jackson participated in the college's inter-echelon courtship rituals, befriending some of her husband's students at the same time as wor- 
rying about his fidelity (Franklin 198). (As it turned out, Hyman, like Langdon, married a former student, albeit after Jackson's death.) The story may therefore voice Jackson's own suspicions about teacher-student relations through the "glowering, resentful" locals (Murphy 124).

It is also possible that, in "The Missing Girl," Jackson identifies herself with Old Jane. As a mother who (in the domestic memoirs Life Among the Savages and Raising Demons) played up the feelings of bewilderment caused by her children, Jackson shares with Jane a baffled sense of responsibility for her charges - not to mention a drinking habit, exposed when Old Jane humiliatingly collapses "dead drunk in front of Chief Hook" (346). Despite this weakness, Old Jane is closer to the hapless yet caring mother Jackson represented herself as in the memoirs than to the monstrous maternal figures in the fiction, especially The Haunting of Hill House as analyzed by Richard Magee and Lynne Evans.

On the other hand, Jackson may also have identified with the missing girl and Paula Welden, as another outsider lost - a key word in Jackson's stories (Franklin 254) - in rural New England. In one respect, Jackson resembled Welden literally from head to toe: when she and Hyman first visited Bennington, she found that "her city shoes were inadequate to the ice" (Franklin 189) of the Vermont winter - an urbanite's lack of preparedness equaled by Welden's going for a hike in December wearing “jeans and lightweight sneakers" (Robinson).

In one respect, a Burkeian reading resolves one dilemma found in other critics' interpretations: how unique was the missing girl among the camp's attendees? Angela Hague thinks Martha Alexander is a typical young woman of the time, whose "lack of a 'private image' or internalized sense of self created the identity crises" (81) that Betty Friedan analyzed and Shirley Jackson fictionalized; but her description of the missing girl as "a person so without personality and individuality that she has made no impression on anyone" (81) seems ironically to single her out from her peers. Bernice M. Murphy likewise describes her as "a colorless teenager" who "made so little impact that no one can even remember her proper name" (109). However, this does not account for the repeated emphasis in the story on how all the girls are felt to be indistinct and interchangeable, perceived generically by their elders within and strangers outside the camp.

Another interpretation sometimes put forward is that the adults deliberately erase the missing girl: Joan Wylie Hall asserts that the uncle has "no clear reason" to claim his niece is at home with her mother, and that Old Jane "does not object to this virtual denial of the girl's existence" (87). Similarly, James Dobson claims that Old Jane and Chief Hook "scrub their 
respective official records clean of any presence of Martha" because it is "much easier and more acceptable" to do so than to admit responsibility for her, and that Betsy and the girl's family deny her existence "to make life easier for themselves"; the remains at the end are assumed to be Martha's, but are "found and buried without much notice" (127). Yet this conspiratorial interpretation does not explain why Betsy would attend the funeral and Old Jane would "come up from New York particularly for the services" (349). Moreover, it does not account for the insistence on forms of social mystery throughout the story.

Offering a corrective to these readings should not be thought to imply that a Burkeian interpretation is contrary to the feminist emphasis on how girls and women of the postwar period found their identities cramped and erased; the point is rather to show how this structural oppression is predicated on and reinforced by the dynamics of difference, classification, and rhetorical manipulation. Burke's theory of the hierarchic psychosis enables us to see the missing girl not as peculiarly unremarkable, but the culminative instance of a problem endemic to hierarchically graded institutions and societies. The adults are not willfully negligent, but unwitting agents of mysteries they are cannot comprehend.

\section{Conclusion}

Given the closeness between them, it is surprising that Jackson scholarship has not drawn upon Burke's theories more often. Though Franklin considers how Stanley Hyman's work on ritual and myth may have influenced the structure of Hangsaman, the possible impact of their prolific friend has rarely been discussed. Darryl Hattenhauer, for example, notes that Burke "mentored her in psychology" in preparation for writing The Bird's Nest (16), and quotes from Burke's letters to Jackson; yet he argues, despite citing none of Burke's critical works, that the "first error of Jackson criticism" - i.e. that she wrote merely "private, apolitical fiction" (191) - is "a long falling off from Kenneth Burke's comment about Jackson's first novel, that central to it is 'the way she gets at the mystery of social class"' (192). Burke's critique of psychoanalysis, that its "stress upon early childhood ... can deflect by leading one to place in terms of familial substance motives that require placement more broadly in terms of social substance" (Rhetoric 281), shows that Burke's theory has a public, rather than a private, apolitical emphasis. Thus, due to misunderstanding Burke's theory, Hattenhauer's claim that Jackson "uses Burke ... and Hyman against themselves" (97) rings hollow. 
Instead, what transpires from a Burkeian reading of "The Missing Girl" is just how dramatically Jackson's representations of hierarchy, mystery, and guilt embody the ideas Burke was developing theoretically. Burke's eye may have been on the geopolitical stage, as evidenced by his concurrent project on Cold War rhetoric, only recently published as The War of Words; but Jackson's fiction demonstrates how courtship and victimage also operate at the local level. Reading Jackson through Burke may therefore feed back into reading Burke through Jackson, supplementing his theorizations in those areas where he paid less attention, especially the lives of women. It is to be hoped, therefore, that more attention will be given to the intellectual cross-fertilization between Shirley Jackson and Kenneth Burke. 


\section{Works Cited}

Burke, Kenneth. A Grammar of Motives. Prentice-Hall, 1945

---. "On Human Behaviour Considered 'Dramatistically." Permanence and Change: An Anatomy of Purpose. University of California Press, 1984, pp. 274-294.

---. "Ralph Ellison's Trueblooded Bildungsroman." Ralph Ellison's Invisible Man, edited by Harold Bloom, Chelsea House, 1999, pp. 93-104.

---. A Rhetoric of Motives. Prentice-Hall, 1950.

Citro, Joseph A. Passing Strange: True Tales of New England Hauntings and Horrors. Houghton Mifflin, 1996.

Dobson, James E. "Knowing and Narration: Shirley Jackson and the Campus Novel." Shirley Jackson, Influences and Confluences, edited by Melanie R. Anderson and Lisa Kröger, Routledge, 2016, pp. 123-141.

Evans, Lynne. “'Help Eleanor Come Home': Monstrous Maternity in Shirley Jackson's The Haunting of Hill House", Canadian Review of American Studies/Revue canadienne d'études américaines, vol. 50, no. 1, 2020, pp. 102-120.

Franklin, Ruth. Shirley Jackson: A Rather Haunted Life. New York: Liveright 2016.

Hague, Angela. “'A Faithful Anatomy of Our Times': Reassessing Shirley Jackson”, Frontiers: A Journal of Women Studies, vol. 26, no. 2, 2005, pp. 73-96.

Hattenhauer, Darryl. Shirley Jackson's American Gothic. SUNY Press, 2003.

Jackson, Shirley. Hangsaman. Penguin, 2013.

---. The Letters of Shirley Jackson, edited by Laurence Jackson Hyman in consultation with Bernice M. Murphy, Random House, 2021.

---. "The Missing Girl." Just an Ordinary Day: Stories, edited by Laurence Jackson Hyman and Sarah Hyman Stewart, Bantam, 1998, pp. 339-349.

---. Raising Demons. New York: Penguin 2015.

Magee, Richard. "Walking Alone: Shirley Jackson's Domestic Gothic." In The Haunted Muse: Gothic and Sentiment in American Literature, Cambridge Scholars Publishing, 2016, pp. 69-92.

"miss." Merriam-Webster.com Dictionary, Merriam-Webster, https://www. merriam-webster.com/dictionary/miss. Accessed 14 Jul. 2021.

Murphy, Bernice M. “'The People of the Village Have Always Hated Us': Shirley Jackson's New England Gothic.” Shirley Jackson: Essays on the Literary Legacy, edited by Bernice M. Murphy, McFarland, 2005, pp. 104-126.

Oppenheimer, Judy. Private Demons: The Life of Shirley Jackson. Putnam, 1988.

Robinson, Rebecca. "After 60 years, student's fate remains a legendary mystery." Bennington Banner. December 1, 2006. https://www.benningtonbanner.com/ stories/after60-years-students-fate-remains-a-legendary-mystery,260506

Wylie Hall, Joan. Shirley Jackson: A Study of the Short Fiction. Twayne, 1993. 